\title{
RGL4 Gene
}

National Cancer Institute

\section{Source}

National Cancer Institute. RGL4 Gene. NCI Thesaurus. Code C113576.

This gene plays a role in guanyl-nucleotide metabolism. 